\title{
Zooplankton abundance and diversity in Lake Bracciano, Latium, Italy
}

\author{
Ornella FERRARA, Daria VAGAGGINI and Fiorenza G. MARGARITORA* \\ Dipartimento di Biologia Animale e dell'Uomo, Università "La Sapienza", Viale dell'Università 32, 00185 Roma, Italy \\ *e-mail corresponding author: fiorenza.margaritora@uniroma1.it
}

\begin{abstract}
The zooplankton community structure in Lake Bracciano (Latium, Central Italy) was studied in monthly surveys throughout an annual cycle (November 1998 - October 1999). The seasonal cycles and population dynamics of the dominant species are described and discussed. Copepods numerically dominated the community throughout the study period with calanoid Eudiaptomus padanus etruscosexsetosus making up the largest share of zooplankton density; moreover it accounted for the largest portion of total biovolume. Cladocerans represented a significant component of the zooplankton in the summer and autumn months. No substantial differences in regard to results of previous investigations $(1971,1972,1984)$ were observed. The only differences for which there is evidence consist of the appearance of Filinia terminalis, never previously found in the lake, and the replacement of Keratella cochlearis instead of Kellicottia longispina as dominant species. However, the results of the comparison of the different investigations confirm that the trophic state of the pelagial region may be classified as oligo-mesotrophic.
\end{abstract}

Key words: zooplankton, seasonal dynamics, lake trophic state, Lake Bracciano

\section{INTRODUCTION}

Lake Bracciano lies on the volcanic plateau of the Sabatini montains near Rome (40 km Nord) at an altitude of $164 \mathrm{~m}$. It is about $57 \mathrm{~km}^{2}$ in area with a maximum depth of $165 \mathrm{~m}$ (Barbanti \& Carollo 1969). The Arrone Stream is the (dam-regulated) outlet of the lake. Bracciano is a warm monomictic lake with stable thermal stratification from May to October and homothermic regime from November to February.

The purpose of the investigation was to determine the species composition and abundance of zooplanktonic communities inhabiting the limnetical and the littoral zones. In this note only information on pelagic assemblages is reported.

The abundance and biovolume of both phytoplankton and zooplankton are largely regulated by the resource base and tend to increase with the trophic state of the lake (Canfield \& Jones 1996). Therefore studies of zooplankton communities in freshwater environments may be instrumental in the prediction of long-term changes in lake ecosystems. Previous investigations of zooplankton in Lake Bracciano started in the early nineteenth century (Losito 1904; Monti 1936; Cannicci 1957; Sommani 1961) and were especially directed towards the identification of taxa and their spatial and seasonal distribution. Subsequent researches (Ferrari 1971, 1972; Ferrara 1984) provided information on taxonomic composition, on seasonal changes in the abundance and biovolume and in life cycles of cladocerans, copepods and rotifers. Detailed information on hydrology and thermal properties, on chemistry and phytoplankton assemblages and on biovolume and diversity of zoobenthos may be found in Barbanti et al.
(1971). This report documents long-term seasonal and annual changes in zooplankton communities and the principal objectives are to describe the recent composition and seasonal cycles of zooplankton and to compare our results with those of previous studies, in order to recognize possible trophic changes. In the last part of the XX Century, urban wastes were channeled into a sewage collection system so that the nutrient loadings from human activities could be reduced. Besides, in summer and autumn changes of water level were recorded, owing to the agricultural and drinking use made of the lake waters.

\section{METHODS}

Samplings were carried out at monthly intervals from November 1998 to October 1999. During the entire period temperature was measured in the central zone of the lake along the water column at $5 \mathrm{~m}$ intervals using an inverted thermometer, and transparency was measured with a Secchi disk (diameter $20 \mathrm{~cm}$ ). In the pelagic zone we chose three sampling stations (Fig. 1): Anguillara (A), Bracciano (B) and the central lake (C). At each station the zooplankton was collected by three vertical tows from $20 \mathrm{~m}$ depth to the surface with a 40 $\mathrm{cm}$ diameter net ( $80 \mu \mathrm{m}$ mesh size) and the three samples were pooled and preserved in 5\% formalin. We also collected vertical samples from $120 \mathrm{~m}$ depth at station C.

The organisms were sorted from representative subsamples in the laboratory and examined under a Utermöhol inverted microscope to calculate the densities (de Bernardi 1974). For each taxon we recorded the developmental stages (nauplii, juvenes or copepodites and adults) and all taxa were identified down to the lowest 
possible taxonomic level, according to Braioni \& Gelmini (1983) (Rotifera), Margaritora (1983) and Smirnov (1996) (Cladocera), Stella (1982) and Einsle (1996) (Copepoda). The biovolume values were obtained by multiplying the unitary volume of each species by the number of animals present in each sample. The unitary volumes were calculated following Nauwerck (1963) and de Bernardi (1974).

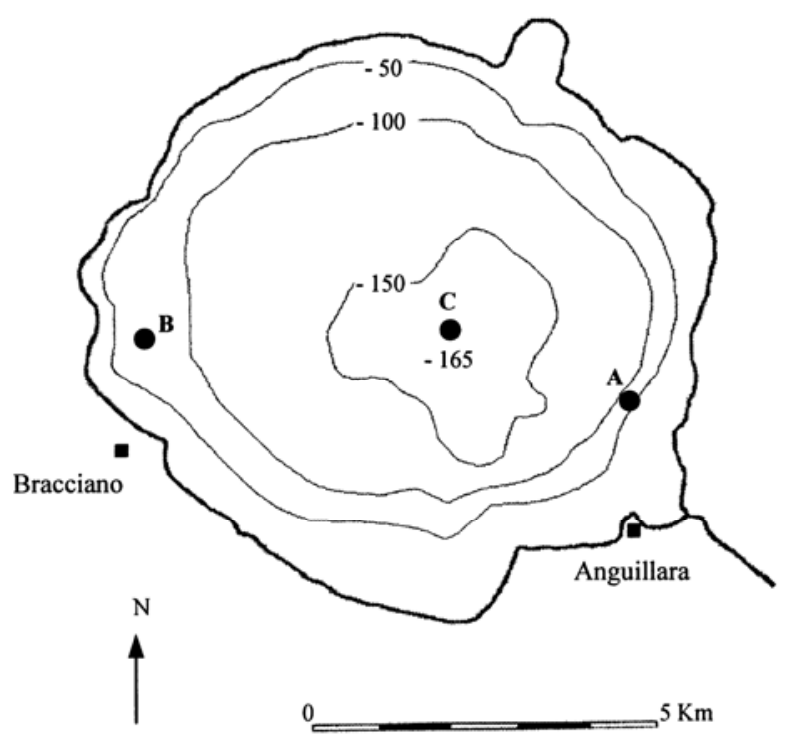

Fig. 1. Sampling stations of zooplankton monitoring in Lake Bracciano.

The Shannon-Weaver Diversity index (H) (Pielou 1969) was calculated for each sample in order to ascertain the structural features of the community while the PSc coefficient (Whittaker \& Fairbanks 1958) was applied to determine zooplankton similarity in the three sampling stations.

\section{RESULTS}

\subsection{Zooplankton composition}

Twenty-one species were identified from collections made in 1998-99 at stations A and B and twenty-four were captured in station $\mathrm{C}$. Of these, seventeen were Rotifera, four Cladocera, three Copepoda (Tab. 1), and exhibited seasonal dynamics as illustrated in figure 2 (mean values for the 0-20 m layer, stations A, B and C). Some species, especially among the rotifers, occurred irregularly, usually in small numbers and were not present in all three stations. Copepods were the dominant group on all sampling dates and accounted for $46 \%$ (July) to 99\% (March) of the total zooplankton density. This group was also dominant in terms of total biovolume (average values), accounting for $2.5 \mu \mathrm{m}^{3} \cdot 10^{11}$ $\mathrm{m}^{-3}$ (minimum, October) and $3 \mu \mathrm{m}^{3} \cdot 10^{12} \mathrm{~m}^{-3}$ (maximum, March) (Fig. 3). While immatures, primarily nauplii, dominated total numbers, adult calanoid Eudiaptomus padanus etruscus made up the greatest proportion of total biovolume in this group. Cyclopoida was not a major contributor to either total zooplankton density or biovolume. Rotifers were the least prevalent of total plankton in terms of density. The mean was actually around $11 \%$ of total numbers over the whole study period. Moreover, the biovolume of this taxon was very low, with average values of $7.3 \mu \mathrm{m}^{3} \cdot 10^{6} \mathrm{~m}^{-3}$ (minimum, January) and $7.5 \mu \mathrm{m}^{3} \cdot 10^{8} \mathrm{~m}^{-3}$ (maximum, June). This group had a summer peak at that time Keratella cochlearis, Kellicottia longispina and Pleosoma truncatum were predominant. Cladocerans were found all year round; the group was second to the Copepoda in terms of density (average value 12\%) and in terms of total biovolume, accounting for $4.6 \mu \mathrm{m}^{3} \cdot 10^{9} \mathrm{~m}^{-3}$ (minimum, March) and $2.6 \mu \mathrm{m}^{3} \cdot 10^{11} \mathrm{~m}^{-3}$ (maximum, November). Diaphanosoma lacustris was the most frequent cladoceran, particularly in late summer, followed by Daphnia hyalina, which was especially representative in late spring. The predaceous cladoceran Leptodora kindtii was a minor component of the group in terms of both numbers and biovolume.

Tab. 1. Zooplankton taxa found in the pelagic zone of Lake Bracciano (November '98-October '99).

\begin{tabular}{l}
\hline ROTIFERA \\
Brachionus patulus (O.F. Müller) \\
Keratella quadrata (O.F. Müller) \\
Keratella cochlearis (Gosse) \\
Kellicottia longispina (Kellicott) \\
Lecane lunaris (Ehrb.) \\
Trichocerca sp. \\
Trichocerca pusilla (Lauterborn) \\
Ascomorpha sp. \\
Synchaeta pectinata Ehrenberg \\
Polyarthra gr. vulgaris dolichoptera Ruttner-Kolisko \\
Ploesoma truncatum (Levander) \\
Asplanchna priodonta Gosse \\
Filinia terminalis (Plate) \\
Hexarthra mira (Hudson) \\
Ptygura sp. \\
Conochilus unicornis Rousselet \\
Collotheca ornata (Ehrenberg) \\
CLADOCERA \\
Diaphanosoma lacustris (Korìnek) \\
Bosmina longirostris (O.F. Müller) \\
Daphnia hyalina Leydig \\
Leptodora kindtii (Focke) \\
COPEPODA \\
Eudiaptomus padanus etruscosexsetosus Kiefer \\
Cyclops abyssorum Sars \\
Mesocyclops leuckarti (Claus) \\
\end{tabular}

We generally observed a comparable temporal evolution of the zooplanktonic community in station $\mathrm{C}(0-$ $120 \mathrm{~m}$ layers) and observed only a slight difference in composition, because three rotifer species (Testudinella patina, Trichocerca pusilla and Lecane lunaris) were found here sporadically and usually in small numbers. 


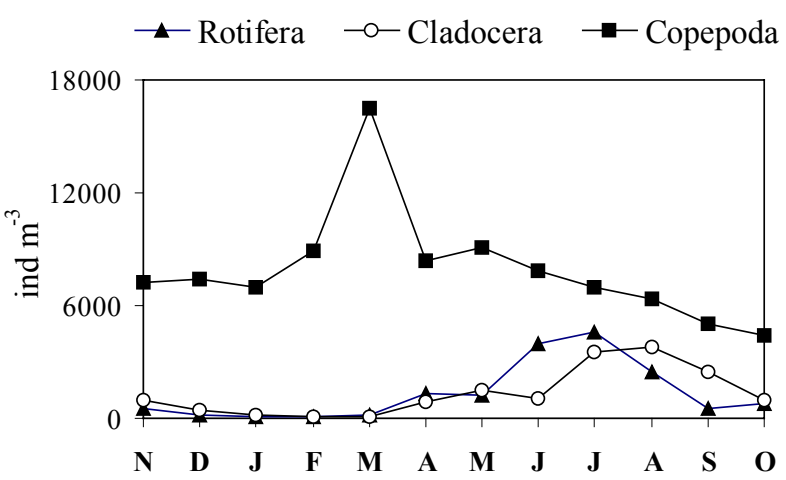

Fig. 2. Density variations of zooplanktonic groups in the three sampling stations $(0-20 \mathrm{~m}$, mean values) during the study period.
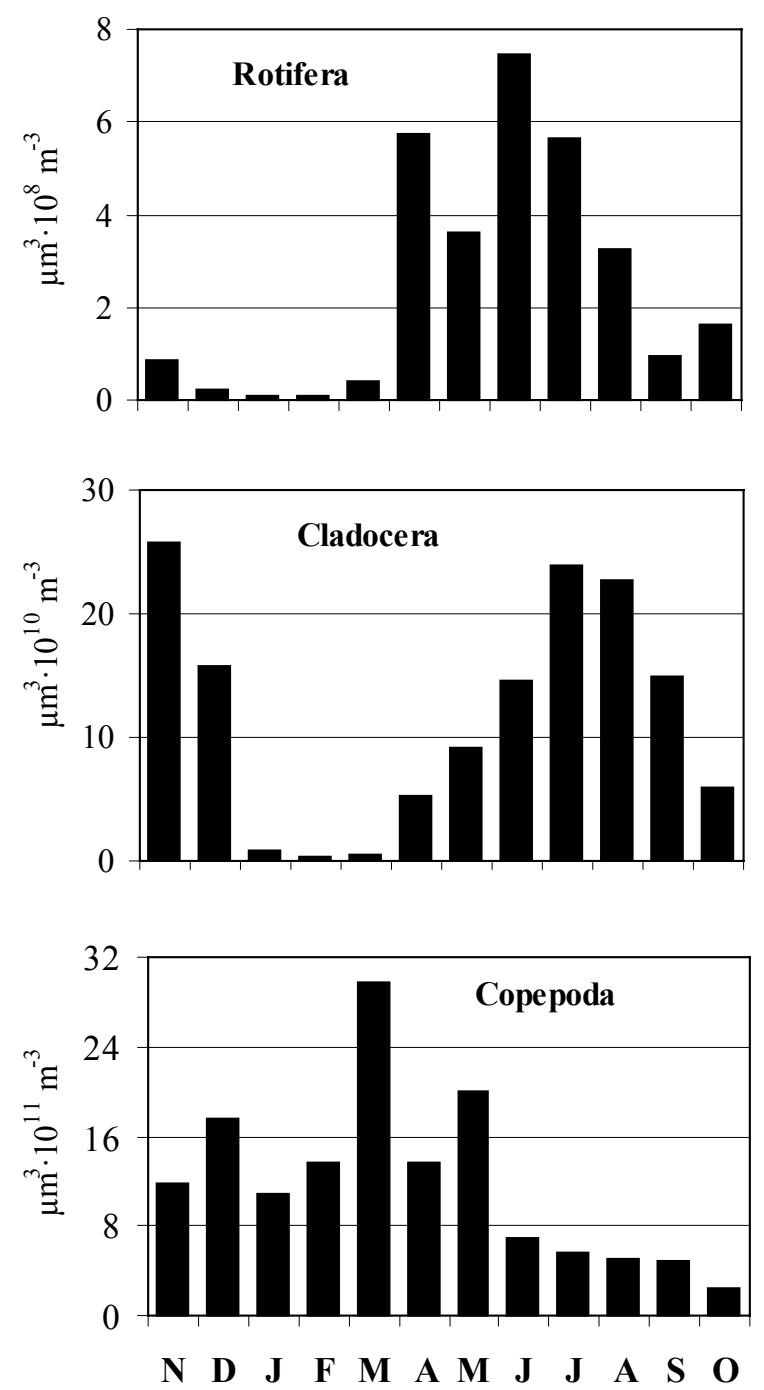

Fig. 3. Changes in the annual biovolume of zooplanktonic groups in the three sampling stations $(0-20 \mathrm{~m}$, mean values $)$ during the study period.

\subsection{Zooplankton seasonal trends}

Seasonal variation in the density and biovolume of the major zooplankton groups showed similar general patterns in all stations. The Copepoda, principally represented by the single calanoid Eudiaptomus padanus etruscus, consistently outnumbered all other groups throughout the study (Fig. 4, mean values at the stations A, B, C; $0-20 \mathrm{~m}$ ) and accounted for most of the yearly zooplankton biovolume. A spring density maximum (March 1999) was observed at all stations, primarily because of a more pronounced development of copepodites and especially nauplii; this peak was particularly pronounced at station B $\left(11,207\right.$ nauplii $\mathrm{m}^{-3}, 12,732$ calanoid copepodites $\mathrm{m}^{-3}$ and 890 cyclopoid $\mathrm{m}^{-3}$ ).
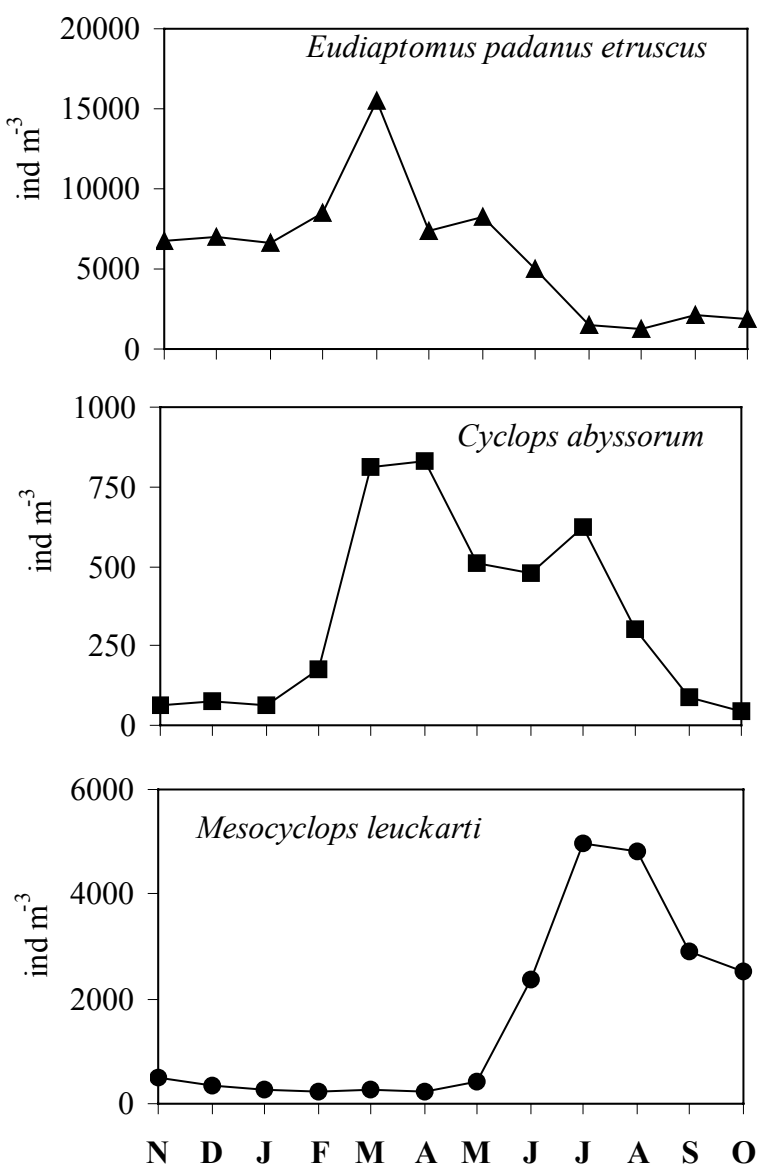

Fig. 4. Seasonal occurrence of the predominant copepod species in the three sampling stations $(0-20 \mathrm{~m}$, mean values) during the study period.

Nauplii exhibited a second smaller peak in summer 1999. Adult diaptomids exhibited a large spring peak in numbers and then declined to a lower summer population. Mesocyclops leuckarti displayed a less pronounced density peak in summer, but maintained a more stable fall and winter population. Cyclops abyssorum did not appear as frequently as Mesocyclops; the development of this species was mainly limited to the cold spring 

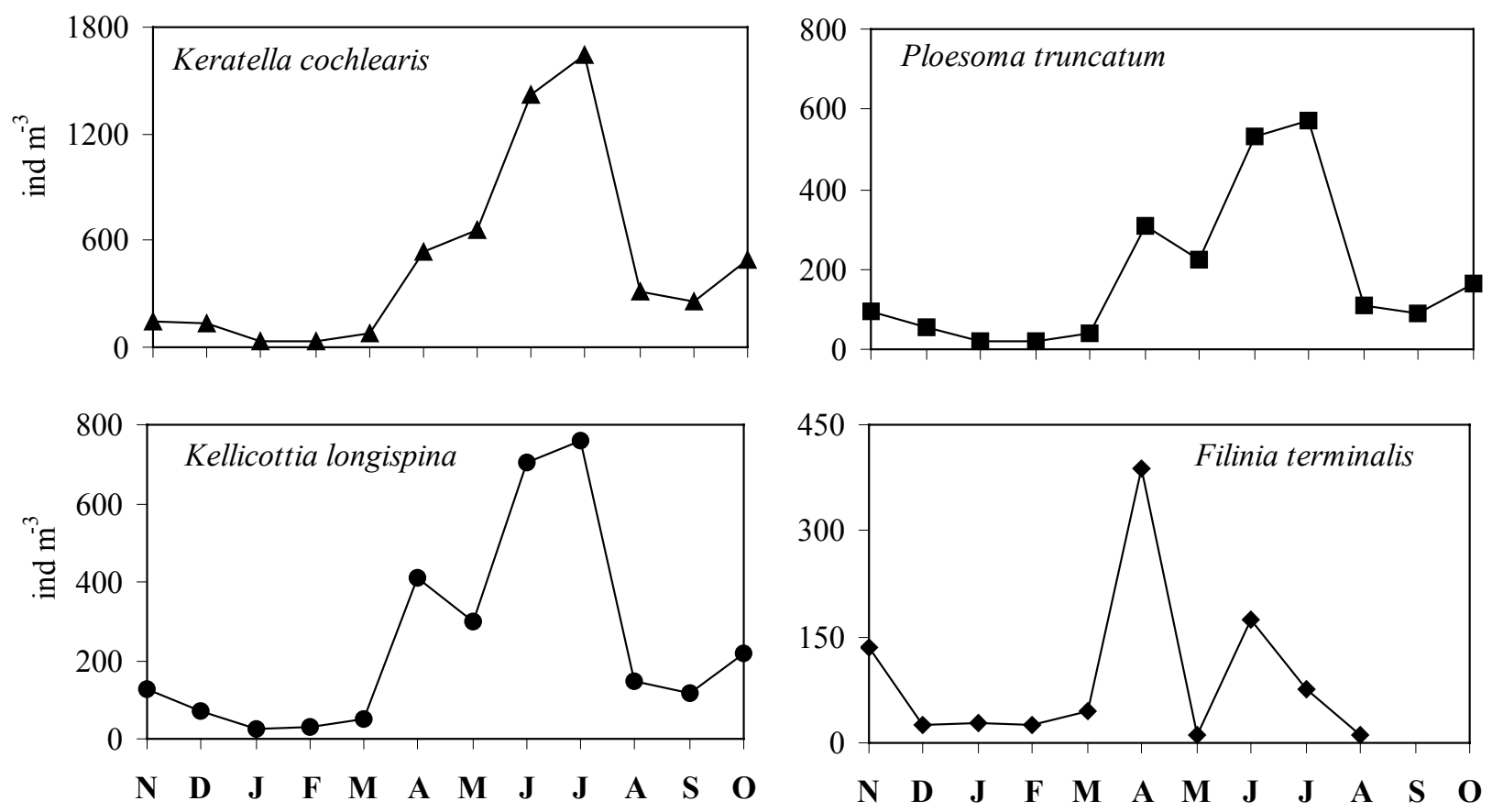

Fig. 5. Seasonal occurrence of the predominant rotifer species in the three sampling stations $(0-20 \mathrm{~m}$, mean values) during the study period.

months, as has been observed in some investigations (Ravera 1954; IRSA 1974; Negri \& Pelaia 1990; Salmaso \& Naselli-Flores 1999).

Among Rotifera, the perennial species Keratella cochlearis (Fig. 5) exhibited a marked density peak in summer before experiencing a gradual population decline. The species persisted throughout the winter in low numbers, achieving a moderate increase in April. Pleosoma truncatum showed a seasonal cycle similar to that of $K$. cochlearis, although the peak was less pronounced. Kellicottia longispina was observed in large numbers during the latter part of the summer while Filinia terminalis, found at low densities, showed a spring increase. The other rotifers were collected occasionally. Similar seasonal trends were observed at all study stations.

Seasonal trends of the main cladoceran species are presented in figure 6. The most frequent species (Daphnia hyalina and Diaphanosoma lacustris) displayed their higher densities only from spring to early autumn; moreover the timing of maximum increase and seasonal replacement of these species was comparable in the three lake stations. Daphnia exhibited a seasonal cycle with a well developed spring maximum in a restricted period (April and May); in the other months densities were generally lower. The phenomenon of summer depression in the daphnid populations has also been reported by many authors (Barry 1997; Manca et al. 2000; Beenndorf et al. 2001). Absent during the late winter months, Diaphanosoma began a population surge in late May, reaching the highest densities during the warmer months. Competitive mechanisms between Daphnia and Diaphanosoma could explain the alternating development of these two cladocerans, as evidenced by many authors (de Bernardi \& Canali 1975; Horn \& Horn 1990). The density decrease observed in Daphnia might also explain the peak values of Bosmina longirostris in July, followed by a rapid decline and disappearance from the open water by August. The predaceous Leptodora kindtii was sporadically collected in samples.

As shown in figure 7 , the diversity values do not have important fluctuations, but a very clear trend over time: low values in winter, when the community was dominated by Eudiaptomus and rotifers, and a rapid increase from April to June, when the community was comprised of a large number of species (particularly rotifers) with no distinct dominance. From June to October high values are maintained. Communities structured in this manner are generally characteristic of stable physicochemical environments (McClintock \& Wilhm 1977). No differences in plankton communities were found in the three stations; PSc values were actually very high and varied between $83.62 \%$ (stations A-C) and $93.93 \%$ (stations B-C). The same situation had been observed in a previous study (Ferrara 1984).

\section{DISCUSSION}

In Lake Bracciano, as in Northern and Central Italian lakes, zooplankton populations are generally low in winter, increase in spring and decline in autumn to low winter levels (Polli \& Simona 1992; de Bernardi \& Ca- 
nale 1995; Salmaso \& Naselli-Flores 1999; Brizzio et al. 2001). We recorded 24 species in the lake plankton. This is well within the range (17 to 27 species) of total species numbers reported for other great lakes in Central Italy (Ferrari 1971, 1972; Margaritora et al. 1988).
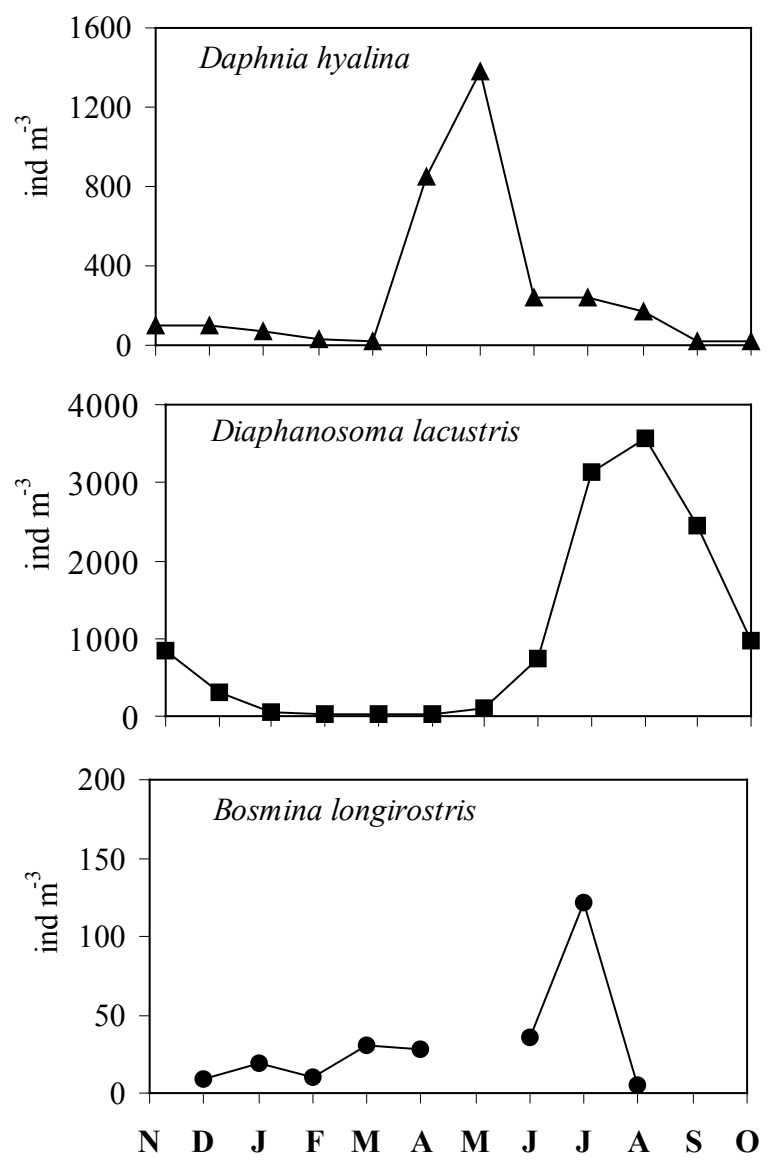

Fig. 6. Seasonal occurrence of the predominant cladoceran species in the three sampling stations $(0-20 \mathrm{~m}$, mean values) during the study period.

Predominant species may have more functional importance than total species numbers in the zooplankton community. Pennak (1957) claimed that in limnetic plankton communities only one to three copepods and two to four cladocerans were normally predominant. Indeed, usually one copepod and two cladocerans were numerically dominant in Lake Bracciano at any one time. The species identified show a wide ecological valence and are commonly distributed in the deep lakes of Central Italy. Our results confirm those of other studies indicating that calanoid copepods are the dominant species in the communities of the pelagic zone of large lakes (Sager \& Richman 1991; Carter et al. 1995; Andronikova 1996) and under oligo-mesotrophic conditions (Sager \& Richman 1991; Elser \& Goldman 1991; Maier 1996). Conversely, a predominance of cyclopoids over calanoids was observed by some workers (Gliwicz 1969; Patalas 1972; Karabin 1983, Maier \& Buchholz
1996) at high trophic levels. Among cladocerans, the predominance of Daphnia hyalina and Diaphanosoma lacustris (identified as Diaphanosoma brachyurum in Ferrari 1971, 1972 and Ferrara 1984) is characteristic of oligo-mesotrophic lakes probably because of a more efficient filtering apparatus of large-size forms (Sommer 1994). Particularly the former exhibited a spring pulse and a decrease in the other months, while Diaphanosoma shows its maximum development in summer and autumn. Similar seasonal replacement among the two phytophagous cladocerans was observed in the investigations carried out in limnetic environments (DeMott \& Kerfoot 1982; Salmaso \& Naselli-Flores 1999). The alternation between the two species might be due to competitive mechanisms (de Bernardi \& Canali 1975; Horn \& Horn 1990) which perhaps also influence the coexistence with Bosmina (DeMott \& Kerfoot 1982).

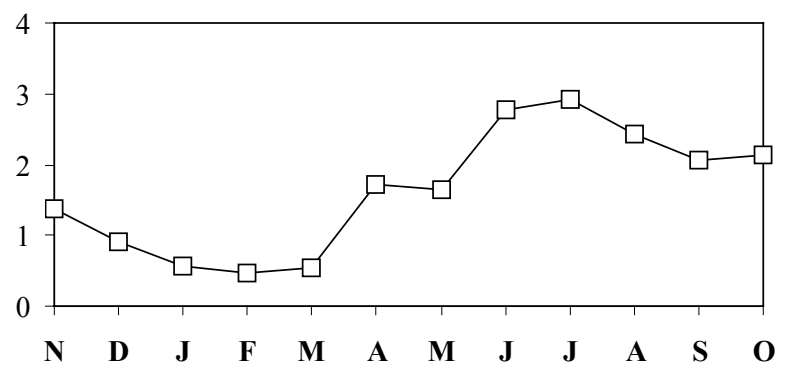

Fig. 7. Seasonal trend of Shannon Index in the three sampling stations $(0-20 \mathrm{~m}$, mean values) during the study period.

Within the rotifers, the presence of Kellicottia longispina and Collotheca ornata confirms a low trophic status for the lake, also in agreement with the results of Gannon \& Stemberger (1978). Nevertheless some authors suggest that rotifers react less to different trophic levels given that some species, e.g. Keratella cochlearis, which is typically predominant in eutrophic lakes (Gliwicz 1969), were observed both in eutrophic and oligo-mesotrophic lakes (Maier \& Buchholz, 1996).

Shannon diversity Index values ranging from 0.46 to 2.92, confirm that Lake Bracciano is home to a zooplanktonic community characteristic of stable physicochemical environments. Moreover PSc values show considerably high similarity among the stations, which does not seem to be affected by anthropogenic pressure.

Although substantial affinities in taxonomic composition and seasonal succession are observed among the data reported in previous works regarding Lake Bracciano zooplankton, our results nevertheless indicate that there are some differences. While the dominance of Eudiaptomus among the copepods is in agreement with the results of previous works, the two species of cyclopoids are present with a lower number of individuals and with a different trend during the three study periods. The numerical prevalence of Mesocyclops over Cyclops observed in the '80s (Ferrara 1984) is also confirmed by the our investigations; in the early '70s (Ferrari 1971, 
1972) the relative importance of these two species appeared inverted in favour of Cyclops. Among the cladocerans, abundant populations of Diaphanosoma and Leptodora, typical summer species in temperate lakes, were observed in all samples in the '70s and '80s. This behaviour was ascribed to a less extreme lake thermal regime (Barbanti \& Carollo 1971). Conversely, in '90s, the latter species, the density of which was generally low, seems to be related to warmer temperatures and is never found in the cold months. Important changes have also taken place in the qualitative composition of rotifers, which is now characterized by the recovery of Filinia terminalis, unreported in any previous results. The seasonal trend of this species, characterized by low densities and a spring peak, is linked to oligo-mesotrophic environments (Ruttner-Kolisko 1980; Laxhuber 1987). Another difference is due to the dominance of Keratella cochlearis over Kellicottia, which was reported as a perennial and dominant species with a spring peak in the '70s and '80s. Other differences in the rotifers group appear of secondary importance, such as the occasional finding of rare taxa typical of littoral fauna.

Finally all data on zooplankton indicate that Lake Bracciano has features typical of deep lakes with moderate productivity. Calanoids actually prevail over other taxonomic groups both in total number and in biovolume; no substantial differences in qualitative composition were found with regard to previous works, with the exception of the appearance of a new rotifer (Filinia terminalis); among cladocerans and rotifers the predominant species are seen to be typical for low productivity water bodies. The comparison of the different investigations seems to suggest a substantial stability in the formerly documented oligo-mesotrophic status of the lake, although on the basis of non-continuous investigations. The mean value of transparency $(10.7 \mathrm{~m}$ in our sampling period), $\mathrm{P}_{\text {tot }}$ values $\left(9.3 \mu \mathrm{g} \mathrm{l}^{-1}\right.$, September $1999 ; 8.4 \mu \mathrm{g} \mathrm{l}^{-1}$, February 2000) and $\mathrm{N}_{\text {tot }}$ values $(290 \mu \mathrm{g}$ $1^{-1}$, September 1999 and February 2000) (Tartari, personal communication) confirm trophic evaluations merging from biological investigations.

\section{ACKNOWLEDGMENTS}

This research was undertaken with the financial support of $40 \%$ MURST. We thank Michela Foschi for her assistance in the field and Luciana Mastrantuono for expert assistance with Cyclopoida identification.

\section{REFERENCES}

Andronikova, I.N. 1996. Zooplankton characteristics in monitoring of Lake Ladoga. Hydrobiologia, 322: 173-179.

Barbanti, L. \& A. Carollo 1969. Batimetrie e geomorfologia dei laghi Sabatini (Bracciano, Martignano, Monterosi). Mem. Ist. ital. Idrobiol., 25: 161-196.

Barbanti, L., G. Bonomi, A. Carollo, G. Chiudani, I. Ferrari, M. Gerletti, A.M. Nocentini, D. Ruggiu \& L. Tonolli. 1971. Limnologia ed ecologia dei laghi di Bolsena, Bracciano, Trasimeno e Vico: situazione attuale e possibili conseguenze derivanti da una loro utilizzazione multipla. Pallanza, Ist. Ital. Idrobiol. Ed.: 263 pp.

Barry, M.J. 1997. Effects of food limitation, notonectid predation, and temperature on the population dynamics of Daphnia carinata. Int. Revue ges. Hydrobiol., 82: 545-562.

Beenndorf, J., J. Kranich, T. Mehner \& A. Wagner. 2001. Temperature impact on midsummer decline of Daphnia galeata: an analysis of long-term data from biomanipulated Bautzen Reservoir (Germany). Freshwater Biology, 46: 199-211.

Braioni, M.G. \& D. Gelmini. 1983. Rotiferi Monogononti (Rotatoria: Monogononta). Guide per il riconoscimento delle specie animali delle acque interne italiane. CNR $\mathrm{AQ} / 1 / 200: 180 \mathrm{pp}$.

Brizzio, M.C., L. Garibaldi, B. Leoni \& R. Mosello. 2001. La stabilizzazione della stratificazione chimica del Lago di Iseo e le sue implicazioni sulle caratteristiche biologiche. Atti A.I.O.L., 14: 125-136.

Canfield, T.J. \& J.R. Jones. 1996. Zooplankton abundance, biomass, and size-distribution in selected midwestern waterbodies and relation with trophic state. J. Freshwat. Ecol., 11: 171- 181.

Cannicci, G. 1957. Osservazioni sulla distribuzione dei Cladoceri del genere Daphnia in laghi dell'Italia peninsulare. Boll. Pesca, Piscic. Idrobiol., 24: 161-195.

Carter, J.C.H., W.D. Taylor \& C. Tudorancea. 1995. A horizontal gradient in zooplankton community structure, and its implications for the relationships among mesozooplankton, microzooplankton, and phytoplankton. Arch. Hydrobiol., 133: 197-222.

de Bernardi, R. 1974. Popolamento zooplanctonico. In: Indagini ecologiche sul Lago di Endine. Pallanza, Ist. Ital. Idrobiol. Ed.: 225-259.

de Bernardi, R. \& E. Canali. 1975. Population dynamics of pelagic cladocerans in Lago Maggiore. Mem. Ist. ital. Idrobiol., 32: 365-392.

de Bernardi, R. \& C. Canale. 1995. Ricerche pluriennali (1948-1992) sull'ecologia dello zooplancton del Lago Maggiore. Documenta Ist. Ital. Idrobiol., 55: $68 \mathrm{pp}$.

DeMott, W. \& W. C. Kerfoot. 1982. Competition among cladocerans: nature of the interaction between Bosmina and Daphnia. Ecology, 63(6): 1949-1966.

Einsle, U. 1996. Copepoda: Cyclopoida. Genera Cyclops, Megacyclops, Acanthocyclops. Guides to the Identification of Microinvertebrates of Continental Waters of World, 10: $83 \mathrm{pp}$.

Elser, J.J. \& C.R. Goldman. 1991. Zooplankton effects on phytoplankton in lakes of contrasting trophic status. Limnol. Oceanogr., 36: 64-90.

Ferrara, O. 1984. Struttura e dinamica della comunità zooplanctonica in un'area del Lago di Bracciano. Riv. Idrobiol., 23 (2-3): 145-158.

Ferrari, I. 1971. I popolamenti zooplanctonici. In: Limnologia ed ecologia dei laghi di Bolsena, Bracciano, Trasimeno e Vico: situazione attuale e possibili conseguenze derivanti da una loro utilizzazione multipla. Pallanza, Ist. Ital. Idrobiol. Ed.: 186-193.

Ferrari, I. 1972. Structure and dynamics of pelagic zooplankton in Lakes Bolsena, Bracciano and Vico (Central Italy). Mem. Ist. ital. Idrobiol., 29: 209-227.

Gannon, J. E. \& R. Stemberger. 1978. Zooplankton (especially crustaceans and rotifers) as indicators of water quality. Trans. amer. Micros. Soc., 97: 16-35.

Gliwicz, Z.M. 1969. Studies on the feeding of pelagic zooplankton in lakes with varying trophy. Ekol. Pol., 17: 663708.

Horn, W. \& H. Horn. 1990. Long-term relationships between phyto and zooplankton in the meso-eutrophic Reservoir Saidenbach. Arch. Hydrobiol. Beih. Ergebn. Limnol., 33: 749-762. 
IRSA. 1974. Indagini sul Lago di Garda (Ed. M. Gelmetti). IRSA Quaderni 18, Roma: 540 pp.

Karabin, A. 1983. Ecological characteristics of lakes in northeastern Poland versus their trophic gradient. VII. Variations in the quantitative and qualitative structure of the pelagic zooplankton (Rotatoria and Crustacea) in 42 lakes. Ekol. Pol., 31: 303-409.

Laxhuber, R. 1987. Abundance and distribution of pelagic rotifers in a cold, deep oligotrophic alpine lake (Königssee). Hydrobiologia, 147: 189-196.

Losito, C. 1904. Entomostraci pelagici del Lago di Bracciano. Tipografia Nazionale di G. Bertero e C., Roma.

Maier, G. 1996. Copepods communities in lakes of varying trophy degree. Arch. Hydrobiol., 136: 455-465.

Maier, G. \& R. Buchholz. 1996. Zooplankton communities of gravel pits in relation to trophy, dredging activity and macrophyte growth. Limnologica, 26(4), 353-360.

Manca, M., C. Ramoni \& P. Comoli. 2000. The decline of Daphnia hyalina galeata in Lake Maggiore: a comparison of the population dynamics before and after oligotrophication. Aquat. Sci., 62: 142-153.

Margaritora, F.G. 1983. Cladoceri (Crustacea: Cladocera). Guide per il riconoscimento delle specie animali delle acque interne italiane. CNR AQ/1/197: 169 pp.

Margaritora, F.G., E. Stella \& O. Ferrara. 1988. Struttura e dinamica dello zooplancton di un lago vulcanico dell'Italia Centrale (Lago Albano, Lazio). Riv. Idrobiol., 27: 131147.

McClintock, N.L. \& J.L. Wilhm. 1977. Effects of artificial destratification on zooplankton of two Oklahoma reservoirs. Hydrobiologia, 54: 233-239.

Monti, R. 1936. Numeri, grandezze e volumi degli organismi pelagici viventi nelle acque italiane, in relazione all'economia lacustre. Mem. R. Ist. Lomb. Sci. e Lett., 23: 83-137.

Nauwerk, A. 1963. Die Beziehungen zwischen Zooplankton und Phytoplankton in See Erken. Symb. Bot. Upsal., 17: 1163.

Negri, A. \& S. Pelaia. 1990. Analisi dei risultati: lo zooplancton. In: G. Chiaudani \& G. Premazzi (Eds), Il Lago di
Garda. Evoluzione trofica e condizioni ambientali attuali. Commissione delle Comunità Europee, EUR 12925, Lussemburgo: 137-141.

Patalas, K. 1972. Crustacea plankton and the eutrophication of St. Lawrence Great Lakes. J. Fish. Res. Bd Can., 29: 1451-1462.

Pennak, R.W. 1957. Species composition of limnetic zooplankton communities. Limnol. Oceanogr., 2: 222-232.

Pielou, E.C. 1969. An introduction to mathematical ecology. Wiley Inter. Ed., New York: 286 pp.

Polli, B. \& M. Simona. 1992. Qualitative and quantitative aspects of the evolution of the planktonic populations in Lake Lugano. Aquat. Sci., 54: 303-320.

Ravera, O. 1954. La struttura demografica dei copepodi del Lago Maggiore. Mem. Ist. ital. Idrobiol., 8: 109-150.

Ruttner-Kolisko, A. 1980. The abundance and distribution of Filinia terminalis in various types of lakes as related to temperature, oxygen and food. Hydrobiologia, 73: 169175.

Sager, P.E. \& S. Richman. 1991. Functional interaction of phytoplankton and zooplankton along the trophic gradient in Green Bay, Lake Michigan. Can. J. Fish. aquat. Sci., 48: 116- 122 .

Salmaso, N. \& L. Naselli-Flores. 1999. Studies on the zooplankton of the deep subalpine Lake Garda. J. Limnol., 58(1): 66-76.

Smirnov, N.N. 1996. Cladocera: the Chydorinae and Sayciinae (Chydoridae). Guides to the Identification of the Microinvertebrates of the Continental Water of the World, 11: $197 \mathrm{pp}$.

Sommani, E. 1961. Osservazioni sulle variazioni quantitative di Entomostraci planctonici nel Lago di Bracciano. Boll. Pesca, Piscic. Idrobiol., 16: 87-94.

Sommer, U. 1994. Planktologie. Springer-Verlag.

Stella, E. 1982. Calanoida (Crustacea, Copepoda, Calanoida). Guide per il riconoscimento delle specie animali delle acque interne italiane. CNR AQ/1/140: $66 \mathrm{pp}$.

Whittaker, R.H. \& C.W. Fairbanks. 1958. A study of plankton and copepods communities in Columbia Basin, Southeastern Washington. Ecology, 39: 46-65. 